\title{
AKTIVITAS ANTIBAKTERI DAN BIOAUTOGRAFI EKSTRAK DAUN RAMBUSA (Passiflora foetida L) TERHADAP Pseudomonas aeruginosa DAN Klebsiella pneumoniae
}

\author{
ANTIBACTERIAL ACTIVITY AND BIOAUTOGRAPHY OF \\ RAMBUSA LEAVES EXTRACT (Passiflora foetida L) AGAINST \\ Pseudomonas aeruginosa AND Klebsiella pneumoniae \\ Ghani Nurfiana Fadma Sari*, Ismi Puspitasari \\ Fakultas Farmasi, Universitas Setia Budi Surakarta, Jawa Tengah, Indonesia \\ *Penulis Koresponding, e-mail: ghaninurfiana@gmail.com
}

\begin{abstract}
ABSTRAK
Daun rambusa (Passiflora foetida L.) mempunyai khasiat sebagai antioksidan, antidiabetes dan antikolesterol, akan tetapi masih belum banyak informasi ilmiah tentang potensi daun rambusa sebagai antibakteri. Penelitian ini bertujuan untuk mengetahui golongan senyawa aktif dan aktivitas antibakteri dari ekstrak daun rambusa secara difusi. Daun rambusa diekstraksi secara maserasi menggunakan etanol 96\%. Ekstrak yang diperoleh kemudian diidentifikasi kandungan golongan senyawa aktif menggunakan KLT-Bioautografi dan diuji aktivitas antibakteri dengan konsentrasi 20\%, 40\% dan 60\% menggunakan metode difusi agar. Kontrol positif yang digunakan adalah kloramfenikol $0,1 \%$ dan kontrol negatif menggunakan DMSO 5\%. Hasil penelitian menunjukkan bahwa ekstrak etanol daun rambusa efektif menghambat aktivitas bakteri Klebsiella pneumonia dan Pseudomonas aeruginosa. Konsentrasi ekstrak yang paling besar zona hambatnya yaitu konsentrasi $60 \%$ yang dikategorikan kuat. Pengujian aktivitas antibakteri dilakukan dengan metode bioautografi kontak hasilnya menunjukkan terdapat bercak pada kromatogram KLT yang menghasilkan zona hambat. Karakterisasi bercak dilakukan dengan penampak bercak $\mathrm{AlCl}_{3}$ dan diduga bahwa bercak tersebut flavonoid.
\end{abstract}

Kata kunci: antibakteri, Passiflora foetida L, Klebsiella pneumonia, Pseudomonas aeruginosa

\section{ABSTRACT}

Rambusa leaf (Passiflora foetida L.) has antioxidant, antidiabetic, and anti-cholesterol properties, but there is still not much scientific information about its antibacterial potential. This study aims to determine the class of active compounds and antibacterial activity of rambusa leaf extract by diffusion. The rambusa leaves were extracted by maceration using $96 \%$ ethanol. The essence obtained was then identified the content of the active compound using TLC-Bioautography and tested for antibacterial activity with concentrations of 20\%, 40\%, and 60\% using the agar diffusion method (Kirby and Bauer). The positive control used was $0.1 \%$ chloramphenicol, and the negative control used 5\% DMSO. The results showed that the ethanolic extract of rambusa leaves effectively hindering the antibacterial activity of Klebsiella pneumonia and Pseudomonas aeruginosa. The extract concentration with the most inhibition zone has a concentration of $60 \%$ has categorized as a great zone. We use the contact bioautography method to 
carry out Antibacterial activity testing. The results showed that there were spots on the TLC chromatogram which resulted in an inhibition zone. The characterization of the node was carried out by looking at the AlCl3 node, and it suspects that the nodes were flavonoids.

Keywords: Antibacterial, Passiflora foetida L, Klebsiella pneumonia, Pseudomonas aeruginosa

\section{PENDAHULUAN}

Klebsiella pneumonia dan Pseudomonas aeruginosa merupakan bakteri patogen, gram negatif yang banyak ditemukan di mulut, kulit, dan usus, namun habitat alaminya di tanah. Penyakit yang ditimbulkan oleh bakteri ini antara lain adalah penyakit infeksi seperti saluran kencing, septicemias, infeksi jaringan bronkopneumoniae, pneumonia (Mayasari, 2006). Antibakteri sintetis biasanya digunakan untuk menghambat atau membunuh pertumbuhan bakteri akibat infeksi yang memiliki beberapa kelemahan, selain harganya mahal, bakteri baik juga ikut terbunuh. Penggunaan antibakteri yang berlebihan dapat mengakibatkan bakteri menjadi resisten. Salah satu alternatif untuk mengurangi konsumsi terhadap antibakteri sintesis adalah dengan mengonsumsi antibakteri alami yang bersumber dari tumbuhan, salah satunya yaitu tanaman rambusa (Passiflora foetida L.)

Rambusa merupakan tanaman yang tumbuh di daerah tropis dan sering merambat pada tanaman lainya, tanaman ini ditemukan di daerah berair rawa. Rambusa memiliki aktivitas antimikroba, antitumor, antikanker, dan antihepatotoksik. Daun rambusa memiliki senyawa metabolit sekunder yang terkandung dalam ekstrak daun rambusa antara lain adalah alkaloid, steroid dan triterpenoid. Senyawa tersebut memiliki potensi sebagai senyawa antibakteri (Noviyanti et al., 2014).

Menurut penelitian (Noviyanti et al., 2014) ekstrak etanol daun rambusa mempunyai aktivitas antibakteri terhadap bakteri Staphylococcus aureus dan Escherichia coli berturut-turut sebesar 12,7 mm dan $9 \mathrm{~mm}$ pada konsentrasi $20 \%$. Suatu zat dikatakan aktif atau tidaknya dapat dilihat dari daerah bening yang dihasilkan, semakin banyak zat aktif yang diserap maka daerah bening yang dihasilkan akan semakin besar. Hal tersebut disebabkan adanya sistem kerja sinergis antar senyawa yang terkandung di dalam metabolit sekunder sebagai antibakteri. Hasil penelitian (Asir et al., 2014) menunjukkan bahwa total kandungan fenol dan flavonoid pada daun rambusa dapat menurunkan peroksidasi lipid dan aktivitas radikal yang dapat menghambat perkembangan bakteri. 
Penelitian ini menggunakan metode analisa bioautografi yang digunakan untuk menunjukkan adanya aktivitas antibakteri. Metode ini menggabungkan penggunaan teknik kromatografi lapis tipis dengan respon mikroorganisme yang diuji berdasarkan aktivitas dari suatu senyawa aktif. Selain itu bioautografi juga dapat digunakan untuk mencari antibakteri baru, kontrol kualitas antimikroba dan mendeteksi golongan senyawa (Colorado et al., 2007).

Berdasarkan latar belakang di atas, maka peneliti tertarik untuk melakukan pengujian aktivitas antibakteri ekstrak etanol daun rambusa terhadap bakteri lain yaitu Pseudomonas aerugninosa dan Klebsiella pneumonia secara in vitro dan mengetahui golongan senyawa aktif yang berperan sebagai antibakteri tersebut melalui uji KLT bioautografi.

\section{METODE PENELITIAN}

\section{Alat dan Bahan}

Peralatan yang digunakan adalah bejana maserasi, corong pisah (Pyrex), cawan porselen, rotary evaporator (Ika), ayakan nomor 40, peralatan gelas (Pyrex), neraca analitik (Matrik), lampu UV, kertas saring, lempeng KLT (Dhevata), tabung reaksi (Pyrex), cawan petri (Pyrex), jarum ose, kapas lidi steril, inkubator (Memmert), gelas ukur (Pyrex), batang pengaduk (Pyrex), boor prof, shaker incubator.

Bahan utama yang digunakan adalah daun rambusa segar yang diperoleh di daerah Wonogiri, Jawa Tengah. Bahan kimia yang digunakan adalah etanol 96\% (Brataco), nheksan (Brataco), kloroform (Brataco), methanol (Brataco), DMSO 5\% (Merck), media Mueller Hinton Agar (Merk), Nutrient Agar (Merck), Brain Heart Infuction (Merck), dan VJA (Merck), kloramfenikol (Merck), bakteri Klebsiella pneumonia ATCC 25923 dan Pseudomonas aeruginosa ATCC 27853.

\section{Jalannya Penelitian}

Determinasi Daun Rambusa

Tahap pertama yang dilakukan dalam penelitian ini adalah melakukan determinasi tanaman untuk menetapkan kebenaran sampel tanaman berkaitan dengan ciri-ciri mikroskopis dan makroskopis, serta ciri-ciri morfologis yang ada pada tanaman terhadap 
pustaka yang dilakukan di laboratorium Biologi Fakultas Matematika dan Ilmu Pengetahuan Alam (MIPA) Universitas Sebelas Maret, Surakarta, Jawa Tengah. Pembuatan Ekstrak

Ekstraksi dilakukan menggunakan metode maserasi. Serbuk daun rambusa sebanyak 500 gram dimasukkan ke dalam maserator, kemudian ditambahkan $5 \mathrm{~L}$ pelarut etanol 96\%. Serbuk direndam selama 6 jam pertama sambil sekali-sekali diaduk, kemudian diamkan selama 18 jam. Maserat dipisahkan dengan cara pengendapan, sentrifugasi, dekantasi, atau filtrasi. Proses penyarian diulangi dengan cara yang sama menggunakan pelarut setengah dari pelarut pertama yaitu sebanyak 2,5 L etanol $96 \%$. Semua maserat dikumpulkan, kemudian diuapkan dengan rotary evaporator hinggaLdiperoleh ekstrak cair dan dilanjutkan penguapan ekstrak di atas penangas air hingga diperoleh ekstrak kental (RI, 2009).

Pembuatan Suspensi Bakteri

Stok bakteri uji K.pneumonia dan P.aeruginosa yang telah diremajakan pada medium NA miring diambil 1 ose, lalu disuspensikan ke dalam $10 \mathrm{~mL}$ medium BHI (Brain Heart Infusion), kemudian diinkubasi dalam shaker incubator dengan kecepatan $100 \mathrm{rpm}$ pada suhu $37^{\circ} \mathrm{C}$ selama 24 jam. Selanjutkan ditambahkan $\mathrm{NaCl} 0,9 \%$ hingga

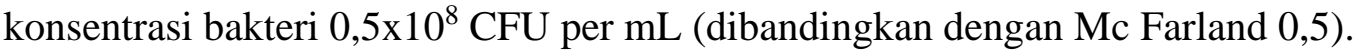

Pembuatan larutan kontrol negatif dan positif

Kontrol negatif yang digunakan dalam penelitian ini yaitu menggunakan DMSO $5 \%$. Cara membuat larutan stok dengan mengambil sebanyak $0,5 \mathrm{~mL}$ DMSO yang dimasukkan dalam gelas ukur, kemudian ditambahkan akuades hingga volumenya $10 \mathrm{~mL}$. Kontrol negatif digunakan sebagai pembanding dan pelarut untuk pembuatan larutan kontrol positif dan pembuatan larutan uji.

Kontrol positif yang digunakan yaitu kloramfenikol. Larutan kloramfenikol 0,1\% dibuat dengan cara melarutkan $50 \mathrm{mg}$ kloramfenikol dalam $50 \mathrm{~mL}$ etanol destilat. Larutan antibakteri kloramfenikol 0,01\% kemudian diencerkan dengan cara dipipet $1 \mathrm{~mL}$ larutan induk kloramfenikol 0,1\% dalam etanol hingga $10 \mathrm{~mL}$. 
Uji aktivitas antibakteri secara in vitro

Ekstrak etanol daun rambusa dibuat 3 konsentrasi yaitu 60\%, 40\%, dan 20\%, masing-masing konsentrasi ditambahkan dengan DMSO 5\% hingga volume $5 \mathrm{~mL}$. Selanjutnya diambil masing-masing $20 \mu \mathrm{L}$ dan dimasukkan ke dalam sumuran pada media MHA padat yang telah diinokulasi pada masing-masing petri dengan kultur bakteri K.pneumonia dan P.aeruginosa, selanjutnya diinkubasi selama 24 jam pada suhu $37^{\circ} \mathrm{C}$. Dihitung diameter zona hambatnya di sekitar sumuran.

\section{KLT Bioautografi}

Bioautografi dilakukan untuk mendeteksi adanya senyawa aktif yang mempunyai aktivitas sebagai antibakteri dari ekstrak daun rambusa. Dalam penelitian ini menggunakan bioautografi kontak. Ekstrak daun rambusa ditotolkan sebanyak $2 \mu \mathrm{L}$ pada plat KLT, dielusi dalam bejana dengan fase gerak heksan : kloroform: metanol = 11:3:6 v/v lalu diangin-anginkan. Kromatogram yang telah dielusi masing-masing diletakkan pada permukaan media MHA (Mueller Hinton Agar) dalam cawan petri yang telah diinokulasi dengan $200 \mu \mathrm{L}$ suspense bakteri Pseudomonas aeruginosa dan Klebsiella pneumoniae yang telah dibuat setara dengan $1,5 \times 10^{8} \mathrm{CFU} / \mathrm{mL}$. Kromatogram kemudian diinkubasi dengan suhu $37^{\circ} \mathrm{C}$ selama 30 menit, setelah itu kromatogram dilepas dari media dan diinkubasi selama 24 jam. Hasil analisis sebagai antibakteri dinyatakan dengan terbentuknya zona jernih pada area kromatogram sebagai zona hambatnya (Kusumaningtyas et al., 2008).

\section{Analisis Data}

Data yang diperoleh dari pengujian terhadap Klebsiella pneumonia dan Pseudomonas aeruginosa secara difusi selanjutnya dianalisa dengan SPSS menggunakan Analysis of Variance (ANOVA) one way dengan taraf kepercayaan 95\%. Metode ANOVA one way digunakan untuk mengetahui adanya variasi konsentrasi aktivitas antibakteri terhadap masing-masing uji dilihat dari angka signifikansi. Syarat uji One Way ANOVA adalah sampel berasal dari kelompok yang saling bebas, data masing-masing kelompok terdistribusi normal, varians antar kelompoknya harus homogen. 


\section{HASIL DAN PEMBAHASAN}

Hasil Determinasi Tanaman Rambusa

Tanaman rambusa yang digunakan dalam penelitian ini telah dilakukan determinasi, dinyatakan bahwa rambusa adalah benar-benar Passiflora foetida L.yang dimaksudkan, sehingga rambusa ini yang akan digunakan selanjutnya dalam penelitian. Data mengenai kebenaran hasil determinasi dapat dilihat pada kunci determinasi berikut. $1 b-2 b-3 b-4 b-12 b-13 b-14 b-17 b-18 b-19 b-20 b-21 a$ 73.

Passifloraceae $1 \mathrm{~b}$ 2. Passiflora 1a-2b-3a-4b Passiflora

foetida L. (C.A. Backer \& R.C. Bakhuizen van den Brink,Jr.). Dari hasil determinasi tersebut bisa dipastikan bahwa sampel yang digunakan adalah benar daun rambusa.

Hasil pembuatan ekstrak etanol daun rambusa

Proses ekstraksi dilakukan dengan metode maserasi menggunakan etanol 96\% dengan tujuan untuk menarik komponen senyawa metabolit sekunder dalam daun rambusa baik yang bersifat polar maupun non polar. Flavonoid merupakan salah satu senyawa dalam daun rambusa yang memiliki kelarutan dalam air-etanol. Hasil rendemen ekstrak daun rambusa yang diperoleh sebesar 14,5\%. Hasil tersebut tidak jauh berbeda dari hasil penelitian sebelumnya yang dilakukan oleh (Guna et al., 2020), diperoleh rendemen sebesar 11,77\% dengan menggunakan metode ekstraksi dan pelarut yang sama.

Aktivitas antibakteri ekstrak etanol daun rambusa terhadap Klebsiella pneumonia dan Pseudomonas aeruginosa

Hasil uji antibakteri secara difusi, diameter zona hambat kloramfenikol yang terbentuk $37 \mathrm{~mm}$ terhadap Klebsiella Pneumoniae dan $22 \mathrm{~mm}$ terhadap Pseudomonas aeruginosa. Pemilihan kloramfenikol sebagai kontrol positif dikarenakan kloramfenikol merupakan antibakteri yang berspektrum luas, sehingga mampu membunuh bakteri gram positif maupun gram negatif (Pratiwi, 2008). Bakteri dikatakan resisten terhadap kloramfenikol apabila diameter hambat pertumbuhan bakteri yang dihasilkan $<20 \mathrm{~mm}$ dan sensitif apabila hasil diameter hambat $>20 \mathrm{~mm}$ (Andrews and Howe, 2011). Dari zona hambat yang dihasilkan tersebut terlihat bahwa kloramfenikol mampu menghambat 
pertumbuhan Pseudomonas aeruginosa dan Klebsiella pneumoniae dengan diameter hambat $>20 \mathrm{~mm}$ maka kedua bakteri tersebut bersifat sensitif terhadap antibiotik kloramfenikol $0,1 \%$. Pada metode difusi sumuran, ekstrak yang memiliki aktivitas antibakteri menghasilkan zona hambat. Metode difusi sumuran digunakan untuk menentukan aktivitas antibakteri dengan membuat sumuran yang diisikan ekstrak sebanyak $20 \mu \mathrm{L}$ pada media berisi agen antibakteri agar yang telah diinokulasi. Area jernih mengindikasikan adanya hambatan pertumbuhan bakteri karena adanya agen antibakteri pada permukaan agar (Pratiwi, 2008).

Kontrol negatif yang digunakan dalam penelitian ini adalah DMSO. Natheer et al., (2012) menyebutkan bahwa zat yang digunakan sebagai kontrol negatif adalah pelarut yang digunakan sebagai pengencer dari senyawa yang akan diuji. Hasil zona hambat kontrol negatif terhadap Pseudomonas aeruginosa dan Klebsiella pneumoniae adalah 0 mm. Hal ini menunjukkan bahwa penggunaan pelarut DMSO tidak mempengaruhi hasil uji antibakteri.

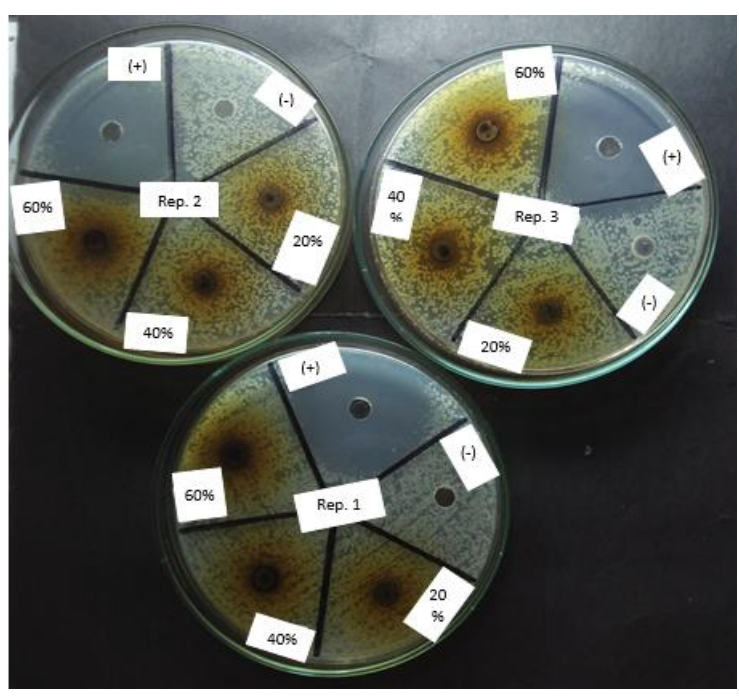

A

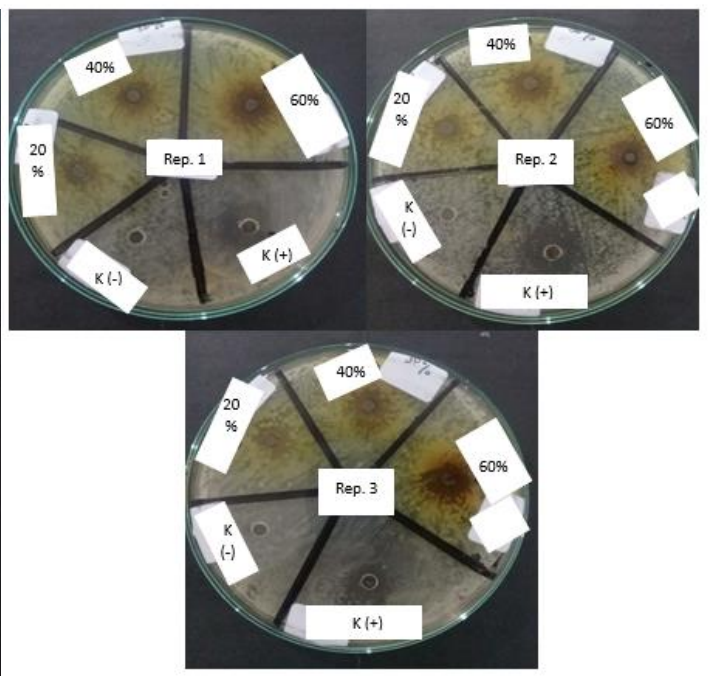

B

Gambar 1. Foto hasil uji difusi ekstrak etanol daun rambusa terhadap bakteri Klebsiella pneumonia (A) dan bakteri Pseudomonas aeruginosa (B).

Keterangan : Kontrol positif (Kloramfenikol 0,1\%), Kontrol negatif (DMSO 5\%)

Ekstrak etanol daun rambusa memiliki aktivitas antibakteri terhadap bakteri Klebsiella pneumonia dan Pseudomonas aeruginosa. Hal ini dapat dilihat dari terbentuknya zona hambat pada sumuran yang berisi ekstrak yang telah diuji terhadap 
bakteri tersebut. Ekstrak etanol daun rambusa menghasilkan zona hambat yang berbedabeda dari masing- masing konsentrasi terhadap bakteri Klebsiella pneumonia dan bakteri Pseudomonas aeruginosa (Gambar 1). Pada konsentrasi 60\% memiliki aktivitas antibakteri paling tinggi dengan luas diameter zona hambat $13,67 \pm 1,53 \mathrm{~mm}$ terhadap bakteri Klebsiella pneumonia dan 15,33 $\pm 1,52 \mathrm{~mm}$ terhadap bakteri Pseudomonas aeruginosa (Tabel I). Dari ketiga seri konsentrasi hasilnya berbeda tetapi tidak signifikan. Menurut (Nazri et al., 2011), suatu zat aktif dikatakan memiliki potensi yang tinggi sebagai antibakteri jika pada konsentrasi rendah mempunyai daya hambat yang besar. Kriteria kekuatan antibakteri adalah sebagai berikut: 1) Daya hambat kuat jika diameter zona hambat 15-20 mm, 2) Daya hambat sedang jika diameter zona hambat 10-14 mm: 3) Daya hambat lemah jika diameter zona hambat 0-9 mm.

Tabel I. Aktivitas antibakteri Klebsiella pneumonia dan Pseudomonas aeruginosa metode difusi

\begin{tabular}{ccccc}
\hline \multirow{2}{*}{$\begin{array}{c}\text { Ekstrak } \\
\text { etanol daun } \\
\text { rambusa }\end{array}$} & \multicolumn{4}{c}{ Rata-rata diameter hambat $(\mathbf{m m}) \pm$ SD } \\
\cline { 2 - 5 } & $\begin{array}{c}\text { kneumonia } \\
\text { plebsella }\end{array}$ & $\begin{array}{c}\text { Kekuatan } \\
\text { antibakteri }\end{array}$ & $\begin{array}{c}\text { Pseudomonas } \\
\text { aeruginosa }\end{array}$ & $\begin{array}{c}\text { Kekuatan } \\
\text { antibakteri }\end{array}$ \\
\hline $60 \%$ & $13,67 \pm 1,53$ & Sedang & $15,33 \pm 1,52$ & Kuat \\
$40 \%$ & $11 \pm 2$ & Sedang & $13 \quad \pm 1,73$ & Sedang \\
$20 \%$ & $7,33 \pm 0,58$ & Lemah & $11,33 \pm 0,57$ & Sedang \\
Kontrol (+) & $37 \pm 1$ & Sangat kuat & $22 \pm 1$ & Sangat Kuat \\
Kontrol (-) & 0 & Lemah & 0 & Lemah \\
\hline
\end{tabular}

Keterangan : Kontrol + : Kloramfenikol 0,1\%

Kontrol - : DMSO 10\%

Hasil uji difusi menunjukkan bahwa ekstrak dengan konsentrasi $60 \%$ memiliki diameter daya hambat yang lebih besar dari konsentrasi $40 \%$ dan $20 \%$. Hal ini dikarenakan ekstrak dengan konsentrasi 60\% lebih banyak mengandung golongan senyawa flavonoid dan alkaloid yang berfungsi untuk menghambat pertumbuhan bakteri Klebsiella pneumonia dan Pseudomonas aeruginosa. Menurut Gunawan dan Mulyani (2004), senyawa flavonoid memiliki aktivitas antibakteri berdasarkan mekanisme flavonoid yang dapat mendenaturasikan protein sel dan merusak membran sel mikroorganisme dan bersifat irreversible atau tidak dapat diperbaiki lagi sehingga pertumbuhan mikroba terhambat. Mekanisme alkaloid sebagai antibakteri dengan mengganggu komponen penyusun peptidoglikan pada sel bakteri, sehingga lapisan sel 
bakteri tidak terbentuk secara utuh karena tidak mengandung peptidoglikan dan dinding selnya hanya meliputi membran sel sehingga menyebabkan kematian sel pada bakteri tersebut (Rachmawaty et al., 2008).

Ekstrak etanol daun rambusa jika dibandingkan dengan kontrol positif (kloramfenikol), diperoleh diameter zona hambat ekstrak lebih kecil. Kloramfenikol 0,1\% diperoleh diameter zona hambat rata-rata $37 \pm 1 \mathrm{~mm}$ terhadap Klebsiella pneumonia dan $22 \pm 1 \mathrm{~mm}$ terhadap Pseudomonas aeruginosa. Mekanisme kerja kloramfenikol dengan menghambat sintesis protein kuman. Obat ini terikat pada ribosom subunit 50s dan menghambat enzim peptidil transferase sehingga ikatan peptida tidak terbentuk pada proses sintesis protein kuman (Setiabudy, 2007).

Hasil uji aktivitas antibakteri dengan KLT bioautografi

KLT-Bioautografi ini dilakukan untuk mengetahui golongan senyawa aktif yang mempunyai aktivitas antibakteri. Hasil uji menunjukkan golongan alkaloid, saponin dan steroid tidak menunjukkan aktivitas antibakteri. Golongan senyawa yang paling aktif dan efektif adalah golongan senyawa flavonoid yang ditandai adanya bercak pada ekstrak dan baku quercetin. Bercak tersebut memiliki aktivitas antibakteri dengan adanya difusi membentuk zona bening. Diameter zona hambat yang terbentuk dari bercak ekstrak rambusa yakni sebesar $5 \mathrm{~mm}$.

Hasil pengamatan pada uji bioautografi yang telah dilakukan terlihat pada media bercak bening yang diyakini sebagai bukti adanya aktivitas antibakteri dari senyawa ekstrak yang telah ditotolkan pada lempeng KLT. Golongan senyawa yang diujikan dalam penelitian ini adalah flavonoid dengan baku pembanding quercetin. Golongan senyawa flavonoid sangat berperan penting dalam aktivitas antibakteri ditandai pada plat KLT yaitu adanya bercak pada ekstrak dan baku quercetin dengan nilai $\operatorname{Rf} 0,2$ pada bakteri uji Pseudomonas aeruginosa dapat dilihat pada gambar 2. Nilai Rf 0,7 pada ekstrak dan baku quercetin terhadap bakteri uji Klebsiella pneumonia dapat dilihat pada gambar 3. Bercak tersebut memiliki aktivitas antibakteri dengan adanya difusi membentuk zona bening. Hasil uji bioautografi menunjukkan bahwa golongan senyawa flavonoid diduga memiliki aktivitas dalam menghambat pertumbuhan bakteri Klebsiella pneumonia dan Pseudomonas aeruginosa. 

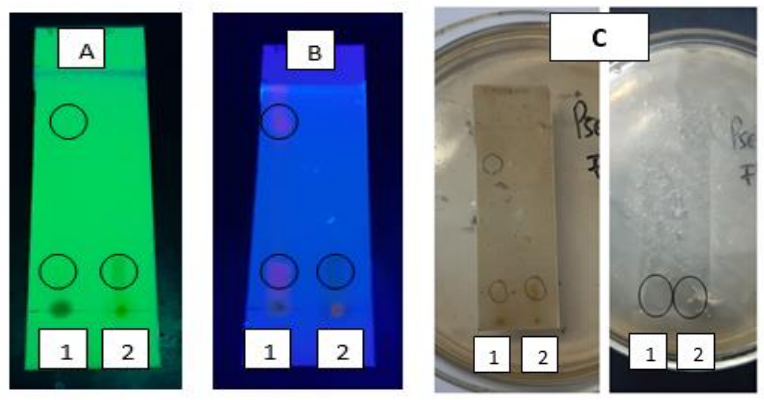

Gambar 2. Hasil uji KLT-bioautografi golongan senyawa flavonoid pada biakan bakteri Pseudomonas aeruginosa.. Keterangan : A (Sinar UV 254 nm), B (Sinar UV 366 $\mathrm{nm}), \mathrm{C}$ (Sinar tampak pada media setelah lempeng KLT dilepas), Ekstrak rambusa (1), Baku Quercetin (2) Fase Gerak : n-heksana-etil asetat (6:4)
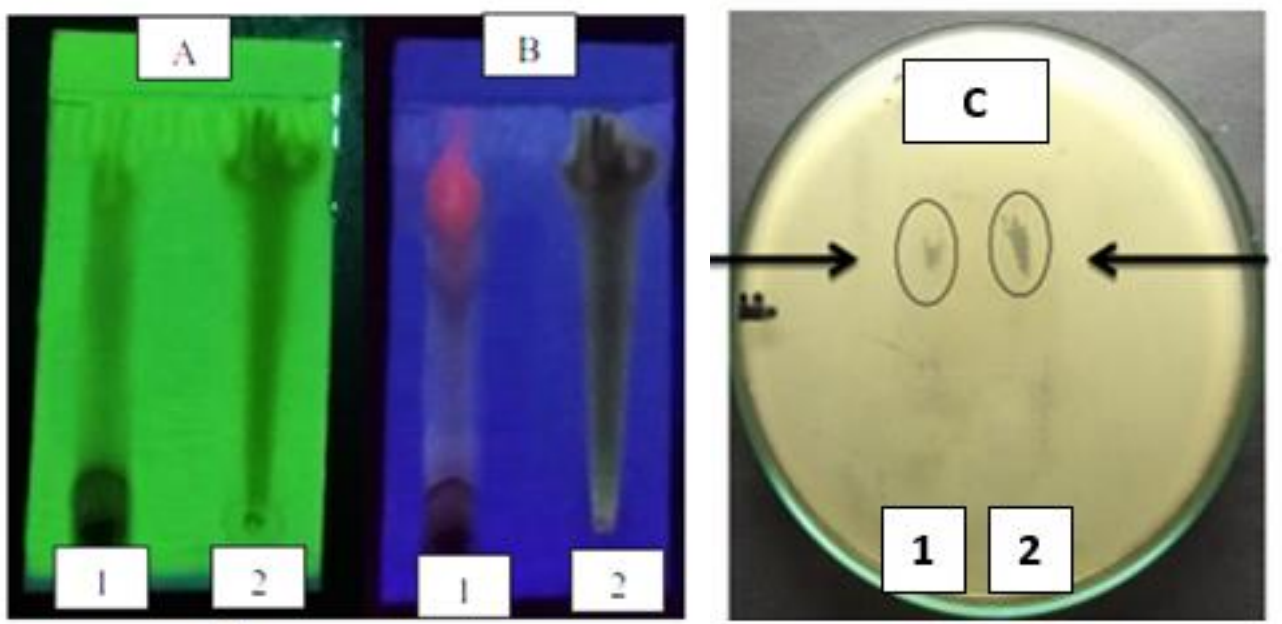

Gambar 3. Hasil uji KLT-bioautografi golongan senyawa flavonoid pada biakan bakteri Klebsiella pneumonia. Keterangan : A (Sinar UV $254 \mathrm{~nm}$ ), B (Sinar UV 366 nm), C (Sinar tampak pada media setelah lempeng KLT dilepas), Ekstrak rambusa (1), Baku Quercetin (2) Fase Gerak : butanol-asam asetat-air (4:1:5)

Untuk mengetahui golongan senyawa yang diduga memiliki aktivitas antibakteri terhadap bakteri Klebsiella pneumonia dan Pseudomonas aeruginosa, maka dilakukan identifikasi senyawa. Menurut (Noviyanti et al., 2014) senyawa dari daun rambusa yang memiliki aktivitas antibakteri antara lain adalah flavonoid, steroid, alkaloid dan saponin. Flavonoid merupakan senyawa polifenol yang mempunyai fungsi sebagai senyawa antibakteri dengan cara mengganggu integritas membran sel bakteri (Wijaya et al., 2014). Dari hasil pengamatan yang dilakukan dengan menggunakan penampak bercak aluminium klorida $\left(\mathrm{AlCl}_{3}\right)$ terlihat terjadi perubahan warna pada bercak pada nilai $\mathrm{Rf}$ 
$0,00,0,33,0,38,0,62,0,7$ menjadi warna kuning. Menurut penelitian yang dilakukan Ahmad (2015) penyemprotan dengan menggunakan $\mathrm{AlCl}_{3}$ untuk mengidentifikasi senyawa flavonoid akan menimbulkan bercak menjadi berwarna kuning sehingga menunjukkan bahwa senyawa tersebut positif flavonoid.

\section{KESIMPULAN}

Ekstrak etanol daun rambusa memiliki aktivitas antibakteri terhadap Klebsiella pneumonia dan Pseudomonas aeruginos. Diameter rata-rata zona hambat yang terbentuk pada konsentrasi $60 \%$ memiliki aktivitas antibakteri paling tinggi yaitu $13,67 \pm 1,53 \mathrm{~mm}$ terhadap bakteri Klebsiella pneumonia dan $15,33 \pm 1,52 \mathrm{~mm}$ terhadap bakteri Pseudomonas aeruginosa. Hasil uji bioautografi menunjukkan bahwa golongan senyawa flavonoid memiliki aktivitas dalam menghambat pertumbuhan bakteri Klebsiella pneumonia dan Pseudomonas aeruginosa.

\section{UCAPAN TERIMAKASIH}

Penulis mengucapkan terimakasih kepada LPPM Universitas Setia Budi Surakarta yang telah mendanai penelitian ini, mahasiswa dan teknisi laboratorium yang membantu di dalam proses pengerjaan hingga mendapatkan hasil penelitian.

\section{DAFTAR PUSTAKA}

Asir, P. Joseph, S. Hemmalakshmi, S. Priyanga, and K. Devaki. (2014). In Vitro Free Radical Scavenging Activity And Secondary Metabolites In Passiflora Foetida L.. Asian J Pharmaceut Res Health Care, 6, 641-644

Andrews, J. M., \& Howe, R. A. (2011). BSAC standardized disc susceptibility testing method (version 10). Journal of Antimicrobial Chemotherapy, 66(12), 2726-2757.

Colorado RJ, Galeano JE, and Martinez MA. 2007. Development of Direct Bioautography as Reference Method for Testing Antimicrobial Activity Of Gentamicin Agains Escherichia coli. Vitae. Vol 14(1):67-71.

Guna, I. M. A. D., Putra, I. N. K., \& Wiadnyani, A. S. (2020). Pengaruh konsentrasi etanol 
terhadap aktivitas antioksidan ekstrak daun Rambusa (Passiflora Foetida L.) menggunakan metode ultrasonic assisted extraction (UAE). Jurnal Ilmu Dan Teknologi Pangan (ITEPA), 9(3), 291-300.

Gunawan D, Mulyani S. 2004. Ilmu Obat Alam. Jakarta: Penebar Swadaya.

Kusumaningtyas E, E, A., \& Darmono. (2008). Sensitivitas metode Bioautografi kontak dan agar Overlay dalam penentuan senyawa antikapang. Jurnal Ilmu Kefarmasian Indonesia, 6(2), 75-78.

Mayasari, E. (2006). Pseudomonas aeruginosa: Karakteristik, Infeksi dan penanganan. Universitas Sumatera Utara.

Nazri, N. A. A. M., Ahmat, N., Syed, S. A., Adnan, A., \& Aris, S. R. S. (2011). In vitro antibacterial and radical scavenging activities of Malaysian table salad. African Journal of Biotechnology, 10(30)

Pratiwi, S. T. (2008). Mikrobiologi Farmasi. Penerbit Erlangga.

Setiabudy, R. (2007). Farmakologi dan Terapi Edisi V. Gaya Baru.

Rachmawaty, F. J., Citra, D. A., Nirwani, B., Nurmasitoh, T., \& Bowo, E. T. (2008). Manfaat sirih merah ( Piper crocatum ) sebagai agen antibakteri terhadap bakteri gram positif dan gram negatif. Jurnal Kedokteran Dan Kesehatan Indonesia, 1(1), $1-10$.

RI, D. (2009). Farmakope Herbal Indonesia,Edisi Pertama. Departemen Kesehatan RI.

Wijaya, B. A., Citraningtyas1, G., \& Wehantouw, F. (2014). Potensi ekstrak etanol tangkai daun Talas (Colocasia Esculenta L.) sebagai alternatif obat luka pada kulit Kelinci. Jurnal Pharmacon, 3(3). 
Nather et al., (2012). Evaluation of Antibacterial Activity of Morindacitrifolia, Vilextrifolia, and Chromolaenaadorata. African Journal of Pharmacy and Pharmacology. 6(11), 783- 788.

Noviyanti, Y., Pasaribu, S. P., \& Tarigan, D. (2014). Uji fitokimia, toksisitas dan aktivitas antibakteri terhadap ekstrak etanol daun Rambusa (Passiflora Foetida L.) terhadap Bakteri Staphylococcus Aureus dan Escherichia Coli. Jurnal Kimia Mulawarman, $12(1), 31$. 